\title{
PRACTICAL PREPARATION OF FUTURE TEACHERS WITH THE HELP OF EDUCATIONAL TRAINING IN PEDAGOGICAL CONFLICTOLOGY
}

\begin{abstract}
The article analyzes actual ideas on the problem of practical training of future teachers. Special emphasis is put on modern student learning technologies. Exclusive attention is paid to the educational training on pedagogical conflictology. The contents, historical aspect, principles, stages, specifics, exercises and techniques of educational training in high school are considered in detail. Presenting main material is to date, there is no generally accepted definition of the concept of "educational training", which leads to its broad interpretation and the designation of this term of various forms, technologies and means used in the educational process of educational institutions. Educational training is characterized by a clear focus on the transfer and provision of personal information in order to form its healthy lifestyle, prevent harmful habits, destructive behavior, vocational guidance, adaptation to society. The educational training is a modern effective tool for the activity of a teacher in a high school, the mastery of which greatly enhances the quality of mastering not only the discipline "Pedagogical conflictology", other training courses, but also the general professional and personal competence and productivity of students for account of saving time, resources, creative perspectives. Also, it should be noted that such a complex phenomenon of educational life as a pedagogical conflict requires a specific comprehensive methodology for its prevention and overcoming. It consists of combining methods, technologies and techniques of individual psychological counseling (for more effective resolution of intrapersonal conflicts) with training technologies (for optimal resolution of interpersonal conflicts). Due to this approach, it is possible to achieve certain positive changes and transformations in the consciousness and behavior of students, to ensure their effective practical training as future teachers of educational institutions.
\end{abstract}

Keywords: higher school, educational training, pedagogical conflicts, practical training of future teachers.

Formulation of the problem. The urgency of the problem of improving the quality of vocational education, improving the practical training of future teachers leads to active searches of modern academic teachers. In part, their exploration is associated with the study of resource opportunities and the prospects of using educational training in the study of humanities. An example of them is, in particular, pedagogical conflictology a theoretical-applied kingship, which is based on the study of the nature, factors of origin, specifics and dynamics of pedagogical conflicts. They arise in the interaction of the participants of the educational process (students, teachers, administration) due to the existence of certain contradictions, contradictions in values orientations, views, mutual expectations, intolerance in communication, destructive actions and lack of conflictological culture of individuals.

All of the above is subjected to constructive influence, correction due to the discipline "Pedagogical Conflictology". It reveals the main categories, the history of its formation and development abroad and in Ukraine, the theory and practice of effective communication in pedagogical conflict, methods and technologies of its solution. The course introduces the students of future teachers to the problems of prevention, typology and dynamics of pedagogical conflicts and provides assimilation of their knowledge, skills and abilities, provides recommendations on possible methods for overcoming pedagogical conflicts. And this is extremely important and necessary for a contemporary controversial educational process in high school.

The urgency of the discipline "Pedagogical Conflictology" is also due to the fact that considerable attention is paid to communication styles, conflict resolution strategies, mediation, advanced educational technologies, techniques for resolving pedagogical conflicts in the form and form of conducting an educational training. It involves the active use of business role-playing games, training exercises, which causes and stimulates a high level of cognitive interest of students, their long-term interest and is one of the most effective interactive tools for the activities of a modern teacher.

Analysis of recent researches and publications is to among the researches of reputable scientists from the nearest foreign countries on multidisciplinary issues of conflict, it is worth noting the works of V. Ageev, O. Antsupov, S. Baklanovsky, F. Borodkin, N. Vishnyakova, N. Grishina, E. Kirshbaum, M. Koryak, V. Olshansky, A. Petrovsky, T. Polozova, O. Shipilov and others.
In Ukraine this problem was successfully developed by I. Bulakh, O. Vynoslavskaya, O. Volyanska, A. Hirnyk, L. Dolinskaya, G. Lozhkin, I. Koshova, N. Korotlenka, V. Kushniryuk, M. Piren, N. Povkuril and others.

In recent decades, domestic scholars have begun to actively focus on pedagogical conflicts in higher education institutions. In particular, G. Kozyrev, I. Kozych, S. Paschenko, G. Shevchenko mainly studied the specifics of social pedagogical conflicts in higher education institutions. G. Antonov, N. Bulatevich, N. Burkalo, I. Vashchenko, N. Volkov considered some aspects of the dynamics of conflicts in high school. I. Singaevskaya, I. Soroka devoted exceptional attention to the prevention of conflicts in the pedagogical collectives of higher education institutions. Interpersonal conflicts in the student environment became the subject of research by K. Lysenko-Gelembuk, N. Makarchuk, L. Matiash-Zayats.

The analysis of scientific literature on the problem of the use of training in general, and in the educational process of educational institutions, in particular, suggests that a significant contribution has been made in this direction: Vachkov I., Maksansov S., Puzikov V., Pometun O., Pirozhenko L., Podimova L., Slastonin V. and others.

The position and conclusions of scientific works of researchers (Zvereva I., Duka O., Kovalev A., Yemelyanov E., Petrovich V., Tsyuman T., Shevchuk O. and others) should be noted about the peculiarities of the training as a method of social-pedagogical activity.

It is impossible to ignore the scientific achievements of the use of educational training in order to develop the communicative and conflictological competence of the individual (Manokhina I., Popova I., Prikhodko V., Tsyuman T. and others).

The purpose of the article is to analyze and characterize the educational training on pedagogical conflicts in the practical training of future teachers. To achieve the goal, the following tasks were implemented:

- the content, history, principles of educational training on pedagogical conflictology are analyzed;

- characterized its specifics and stages;

- substantiated the basic exercises and techniques of educational training on pedagogical conflictology.

Study presentation. There is no generally accepted definition of the concept of "educational training", which leads to its broad interpretation and the designation of this term of various forms, technologies and means used in the 
educational process of educational institutions. Therefore, we consider it necessary to briefly observe the emergence and use of this concept in the fields of scientific knowledge.

Initially, the term "training" (from the English train, training) denoted learning, education, training and was used in sports, medicine and psychology as an intensive way of acquiring knowledge and developing skills and abilities of the individual. In this context, the training was interpreted as a planned process for modifying the attitude, knowledge or behavioral skills of the learner by acquiring his or her learning experience in order to achieve effective performance in one type of activity or in a particular field through training. This is a complex of exercises, a system of preparation of the human body in order to adapt it to the increased demands and difficult conditions of work and life [4, p. 5].

The formation of trainings in a separate method of active learning and the emergence of later versions (personal growth training, sales training, business training etc.) are associated with the name of the American psychologist Kurt Levin. This social psychologist in 1946 created special training groups whose purpose was to improve communication skills. It was noted that effective changes in installations, a more objective analysis of personality traits and their behavior occur when a person works and studies in a group. Later, the National Laboratory of Training was founded, where they began to teach politicians, managers, managers the ability to solve conflict situations, manage, and communicate effectively.

In 1954, there are groups of sensitivity, aimed at developing the ability to feel their own and someone else's state, clarifying the basic values of life and human settings. In the 50 s and 60 s, the concept of "business consultant" appears (they are lecturers from the US universities and research scientists).

Significant contribution to the development of the training process was made by Carl Rogers. In the 60 years of his training of life and social skills used to train managers, teachers, consultants etc. [7].

In 1971, M. Forverg (Germany) developed a method of socio-psychological training. He began to use a variety of role-playing games that promoted the development of communicative skills. M. Forverg taught and trainers from Russia, who later began to conduct their training. Russia trained in the 90's with the development of business and the opening of branches of large multinational enterprises. It was then that there was a need to train new employees in accordance with the standards of the activities of foreign companies and corporations [7].

Today there are a huge number of different training courses of various directions: trainings for negotiations, sales trainings for managers, business trainings, personal development trainings, psychotraining, social psychological trainings, social and pedagogical trainings, educational and educational trainings, and others.

Psychotraining - a method of practical psychology, focused on the use of group psychological work to develop social and psychological competence. Basic psycho training is role games in a variety of options and applications, group discussion.

Socio-psychological training, as a method of group work, according to K. Ruedstam (by the reference I. Vachkov), has the following advantages [1]:

- group experience counteracts alienation, helps in solving interpersonal problems;

- the group reflects the society in a miniature, revealing such hidden factors as partner pressure, social influence and conformism;
- the group is modeled a system of relationships, typical for the real life of participants;

- possibility of receiving feedback and support from people with similar problems and situations;

- in a group a person can learn new skills, experiment with different styles of relationships among equal partners;

- in a group, participants can identify themselves with others;

- the interaction in the group creates stress, which helps to show the psychological problems of each;

- the group facilitates processes of self-disclosure, selfknowledge and self-study;

- group form has advantages and economically: for participants a cheaper group forms of work than individual; a psychologist also receives both economic and temporal benefits [1].

Social-pedagogical training is a form of active social learning that allows a person to self-identify skills in the construction of productive psychological and social interpersonal relationships, to analyze socio-psychological situations from their point of view and the position of the partner, to develop the ability of knowledge and understanding of themselves and others in the process of communication. Social-pedagogical training is a special form of group work with its capabilities, constraints, rules and problems, which helps in the socialization of personality [6, p. 5].

Educational training is characterized by a clear focus on the transfer and provision of personal information in order to form its healthy lifestyle, prevent harmful habits, destructive behavior, exercise vocational guidance, adaptation to society etc. [4, p. 4].

Educational training is a dynamic form of learning, in which an active learning of knowledge, skills and abilities acquired that, meets the conditions of modern life. Educational training is aimed at forming the educational and vital competencies of the individual by enriching both knowledge and life-practical and emotional and personal experience.

Tsyuman T.P. determined that educational training is based on four principles, namely: "1) building on a developing education as a potential for personal development on the basis of interaction logic, rather than influence; 2) the creation of conditions that include the preparation of the person to solve the problem of life situations; 3) opportunities for the person to choose their life path, based on the ability to analyze the situation and be responsible for their behavior, the emerging desire for self-development; 4) protection of each subject of the educational process through overcoming the psychological and pedagogical insecurity of participants, the development and realization of individual potencies "[5, p. 9]. It is precisely in observance of such principles, according to the scholar, the educational training will carry the maximum effectiveness, will promote the widest disclosure of each of its participants, which during active work will not only receive the information ready, but also through methods of thinking will determine the main provisions that will they are aware of it.

Given the basic principles, educational training is not only an element of lifelong learning, but also one of the components of a person-oriented model of education and education, a means of self-realization, self-affirmation and selfdevelopment of the student's personality. Educational training on discipline "Pedagogical conflictology" is based on the purpose and objectives of this course, obligatory for the participants of the educational process.

The purpose of the discipline is aimed at assimilating future teachers of knowledge on the theory and practice of 
pedagogical conflictology; formation of skills, skills necessary for future effective activity related to the prevention and successful resolution of pedagogical conflicts in higher education institutions; achievement of constructive relations in the high school, built on the basis of cooperation. The tasks of studying the discipline consist in the formation of general competencies: the ability to analyze and synthesize; the ability to apply knowledge in practical situations; the possibility of using information and communication technologies; the ability to adapt and act in a new situation. Subject competences: the ability to understand the theoretical and practical principles of pedagogical conflictology; to form conflictological competence of a teacher of a higher education establishment; be able to apply modern methods, technology and techniques of prevention and solving pedagogical conflicts in higher education.

The main tasks of the educational training on discipline "Pedagogical conflictology":

- mastering theoretical and methodological knowledge;

- formation of skills and competences of communication;

- correction of behavioral complexes, necessary for application in practical situations;

- development of competence in the ability of selfknowledge and awareness of the options of the actions of others;

- evelopment of skills in the system of interpersonal relations; development of reflection and congruence, empathy and tolerance.

We describe the basic principles and requirements for the implementation of educational training in pedagogical conflictology. Before all, the success of its implementation depends to a large extent on the teacher, who should make serious efforts in mastering the role of the trainer, which is significantly different from the position of the teacher.

The role of the teacher-trainer is to help participants take as active a part as possible and be certain about an adequate understanding of key concepts and ideas. The trainer also needs to be flexible in behavior and is prepared to adapt the program to the needs and ideas that will arise during the group process. The trainer-teacher structures the content and is responsible for conducting the training. But at the same time he should take into account that the training of students will be more successful in the informal organization of space, minimizing the barriers between him and the student. Such a teacher acts as an assistant who helps the group to identify its resources. His task is to enable each participant to make the most of his or her own experience in such a way as to be able to learn from the experience of another. To do this, keep in mind those students:

- need help, not evaluation; it is necessary to encourage participants to find new ideas, rather than repeating the old ones;

- understand the best success when they are treated as collaborators when they feel that they are respected and appreciated, and not "patronized" and manipulated by them.

Also, during conducting an educational training on pedagogical conflicts, a leading teacher helps:

- creating a general atmosphere of trust and benevolence in the group

- providing favorable conditions for the exchange of experience in the group, the free definition of problems, conflicts, unambiguous consideration of ways to resolve them;

- help participants to motivate learning;

- applies a variety of teaching methods in order to provide diversity classes and customize the various training styles of participants;

- accepts the intellectual content and emotional mood, giving them the same degree of significance;
- establishes and continuously supports a positive group atmosphere and becomes a participant in the educational process;

- identifies himself with the group, imposes and does not require anything $[4, p .8]$.

Equally important in implementing the educational training on discipline "Pedagogical Conflictology" is compliance with the trainer-teacher of the principles of organization and work of the training group. From dyads and small groups to the population of the state are social community cannot exist without the rules that regulate the livelihoods of people. Let's list the main principles without which the training may lose its specificity and become a normal educational process. In addition, the formation of a specific group should also take into account additional factors that can influence the organization of the training.

In the vast majority of cases, the trainer invites participants to reflect on the following question: What is needed to create a work atmosphere, a sense of comfort for all students? Thanks to "Brainstorming", participants propose their own rules of the rules. The coach writes them on the flipchart. Rules are a prerequisite for environmental cooperation in the group; they are the regulators of constructive interaction of the participants.

The rules can be approximately the following:

- be friendly, honest and sincere;

- work "here and now";

- speak of the "I", be responsible;

- keep confidentiality;

- adhere to the regulations;

- speak in turn (hand rule);

- adhere to the "stop" rule;

- be tolerant;

- work in groups from beginning to end;

- be active.

This list of rules can be written in advance on the watches and present at the discretion of students, if necessary, they can supplement it. It is advisable, once the rules have been adopted, to draw the students' attention again to the need for their careful observance. And if necessary, it should continue to do so. In addition, each training participant should put his signature under the rules. Thus, their individual awareness, consent with them and their subsequent personal fulfillment are certified.

For the more effective work of students during the educational training on pedagogical conflicts, the following principles should be taken into account by the lead author. The principle of heterogeneity, it is desirable to combine in the training group of persons who differ in gender, experience, age. It is believed that the most optimal age for participation in the training groups - from 16 to 40 years. Such a group works most productively and it has special processes that promote the self-disclosure of participants, if it is closed, that is, there is a permanent membership of the participants and there is no constant inflow of new members in each lesson. Such communication is based on the mutual respect of the participants, on their trust in each other. This is possible with the full rights of the participants as interlocutors, since in the case of the domination of one of them or several members of the group of communication loses the nature of true dialogue and turns into a monologue that contradicts the nature of the training.

Also, the principle of constant feedback is important, that is, the continuous receipt by the participant of information from other group members about the results of his actions during the training. Thanks to feedback, the student can adjust his next behavior, replacing the unsuccessful ways of 
communicating to new ones, checking the effectiveness of their impact on others. During the educational training there is a constant self-disclosure of participants, awareness and clear formulation of their own personally significant problems. The content of the lessons includes exercises and procedures that help the student to identify themselves, the peculiarities of their personality.

During the training on pedagogical conflictology, not only a clear diagnosis and a qualified statement of a particular psychological state of individual participants and the group as a whole, but also an active intervention in an event that occurs to optimize the conditions necessary for personal development. On the one hand, the training is characterized by high emotional warmth, participants frankly experience events in the event group. However, on the other hand, the training also activates intelligent analytical processes - discussion of events. For any training, the alternation of intellectual and emotional stress is fundamentally important, as the duration of homogeneous occupations may lead to overtime and reduce the efficiency of the conducted studies.

An absolute requirement is the complete confidence of the students that nobody listens to them. If the conductor needs to conduct audio or video lessons, he must obtain the consent of all members of the group. In the premises for classes participants must have the opportunity to move freely, settle in a circle, unite in a micro group of 3-5 people, 7-8 people, as well as for solitude.

So, during the work of the training group there is a series of stages of its development. The most important of these are: 1) acquaintance and orientation; 2) labialization; 3) constructive, purposeful activity; 4) completion of the process and the training procedure.

At first, the relations of participants are regulated by purely emotional impressions, sympathies, antipathies; a greater role is played by the appearance of a person, his physical data. Then the labialization comes. Sometimes it is called a stage of confrontation with the leader. Group members get information about themselves, which contradict their own, long-standing ideas. There is a tension that can be expressed in the aggressive behavior of group members in relation to the host or other students. Such processes are normal and even desirable and confirm the group dynamics, development of the group. Then naturally there is a constructive, purposeful activity.

At this stage, the participants of the training realize the ability and ability of self-disclosure to the group about their personal problems; the relationships gain the character of trust, mutual respect, learning from the experience of others, and others like that.

A special significance in the process of mastering the students of the discipline "Pedagogical Conflictology" acquires and the scheme of the training session. The scheme proposed in the first lesson is repeated on all subsequent ones. Because of its repeatability, it also acts as a norm for a specific group. For this reason, in the scheme of classes, as a rule, there are positive moments that create conditions for the productive effect of the training.

Some elements (greetings, ending classes and moments of mutual support) are introduced from the very beginning by the trainer, others - are worked out during the work and are offered by the participants themselves.

Therefore, it is desirable to follow the following algorithm during the conducting of an educational training on discipline "Pedagogical Conflictology":

- I. Greeting. It is clarifying the well-being of everyone. This creates an atmosphere "here and now." By showing their emotional state, the participants tell what they expect from the class, about the changes that have occurred as a result of the previous occupation. The trainer offers to the topic of study in accordance with the work program of the educational discipline "Pedagogical Conflictology". Sometimes, the topic of classes in relation to previous student statements can vary in their sequence.

- II. Exercise for emotional warm-up. It is aimed at creating the internal freedom of the group members. The repertoire of such games is considerable and they are mostly taken from children's games. These exercises are combined to create a positive attitude for students for the further comfort of the group.

- III. The main part is that carries the main content load. In it, exercises passive character alternate with mobile games. They end with compulsory discussion and self-report of the participants about their feelings and thoughts (reflection).

- IV. Summing up the sessions. Speaking participants in turn about their feelings, impressions about the work done, wishes of the trainer and the group.

- V. Farewell. It is a kind of ritual action and can have different forms of conduct. The main thing is that farewell takes place "on the positive" and in the major mood of the participants in the training group [4, p. 32-34].

Given the specifics of conducting an educational training on pedagogical conflictology, we will mention its more qualitative and more commonly used exercises and techniques.

1. Exercises-dating and self-presentation, portfolio. Short emotionally positive exercises are which intended for the logical beginning of employment. Help participants relax, get acquainted, create an atmosphere of trust in the group. They should encourage participation and mutual support.

2. Play emotional warm-ups. They are useful for increasing the energy level and encouraging further student work. They can also increase the meaning of the basic meaning of exercise in an easy and comfortable way.

3. Group discussions. Discussion - collective discussion of controversial issues, problems, conflicts. Unlike a quarrel, it does not lead to confrontation, but unites. The discussion aims to comprehensively discuss the subject of the dispute and is conducted in both large and small groups. 4. Technique "Detection of emotions". It is aimed at understanding, mastering, naming and demonstrating by students, in a socially acceptable format, their positive and negative emotions that arise in the process of interaction of the training group. In this way, students get rid of various types of aggression, anxiety, fear, and gain a positive experience of substituting emotions.

5. "Brainstorming". Effective technique of activating the creative thinking of students, a kind of heuristic communication on the discussion of new ideas, having a subject of a problem, a conflict situation, and the goal - its solving.

6. Business game. Its purpose is to determine the attitude of the individual to a particular life conflict situation, to gain important experience through the game. A business game can be used to get specific skills. Participants can play their own actual problem situations in which they have already visited and need more rational ways of resolving conflicts.

7. Creative activity. You can use the following types of creative activity: drawings, collages, drawings, compilation of stories, analysis of folding and humor and the continuation of unfinished sentences, phrases in order to design outside the information space of the group of thoughts, positions, and experiences of students [3]. 
Only a few training exercises and techniques are presented in this article, but it is important to remember that they should be chosen according to the expediency of a particular group of students, its specifics, the request, previous experience and the topics of discipline "Pedagogical Conflictology".

It is just as important to finish a training session correctly as to start it correctly. Conducting planned exercises at the end of the training course will help participants repeat the material they have trained and determine how to put them into practice and use the information in practice. Usually, participants like that at the end of the training, you can check the theoretical knowledge in applied work. A trainer can accurately collect information and exercises that are relevant to the training course and, if necessary, adapt this activity. Examples of final exercises include written evaluation questionnaires, or feedback forms.

Conclusions and perspectives of further research. Summing up the aforementioned, one can conclude that educational training is a modern effective tool for the activity of a teacher in a high school, the mastery of which greatly enhances the quality of mastering not only the discipline "Pedagogical conflictology", other training courses, but also the general professional and personal competence and productivity of students for account of saving time, resources, creative perspectives.

Also, it should be noted that such a complex phenomenon of educational life as a pedagogical conflict requires a specific comprehensive methodology for its prevention and overcoming. It consists of combining methods, technologies and techniques of individual psychological counseling (for more effective resolution of intrapersonal conflicts) with training technologies (for optimal resolution of interpersonal conflicts). Due to this approach, it is possible to achieve certain positive changes and transformations in the consciousness and behavior of students, to ensure their effective practical training as future teachers of educational institutions.
References

1. Vachkov IV. Basics of technology are of group training - M. : "Osse89", 1999. - $172 \mathrm{p}$

2. Koshechko N.V. Principles, methods and technologies of teaching students of higher educational institutions in pedagogical conflictology: general theoretical (S. Kh. Chavdarov) and contemporary empirical aspects I N.V. Koschechko // Contribution by S. Kh. Chavdarov (1892-1962) in the development of pedagogical science and practice: materials of scientific and pedagogical readings devoted to the 125-th anniversary of the birth of S. Kh. Chavdarov, September 22, 2017 / in the wording of A. A. Marushkevich. - Nizhyn: PE Lysenko M.M., 2018. - P. 61-85.

3. Koschechko N.V. Training "Youth Chooses Constructive Conflict" / N.V. Koschechko // Practical Psychology and Social Work: Scientific-Practical and Educational-Methodical Journal. - N 8-11/2005.

4. Petrovich V. S. I want to be a coach: a table-book of a beginner coach / Authors-compilers: Petrovich V. S., Zakusilo O. Yu., - Lutsk, 2004. - 70 p.

5. Tsyuman T. P. Formation of culture of life self-determination of senior pupils by means of educational training: author's abstract. dis Cand. ped sciences for special 13.00.05 - social pedagogy. - Institute for Education Problems of the Academy of Pedagogical Sciences of Ukraine, Kyiv, 2008. - 20 c.

6. Shevchuk O. M. Organization and methodology of socio-pedagogical training : textbook // Instruction: O. M. Shevchuk. - Uman : PP Yellow, 2011 - 133 p.

7. History of training. [Electronic resource]. - Access mode: https://www.rbc.ua/ ukr/digests/istoriya-vozniknoveniya-treningov-18072013122100

\section{Список використаних джерел}

1. Вачков И. В. Основы технологии группового тренинга / И.В. Вачков. М. : изд-во "Ось-89", 1999. - 172 с.

2. Кошечко Н.В. Принципи, методи та технології навчання студентів ВНЗ з педаго-гічної конфліктології: загально-теоретичні (С.X. Чавдаров) та сучасні емпіричні аспекти / Н.В. Кошечко // Внесок С.Х. Чавдарова (1892-1962) в розвиток педагогічної науки і практики: матеріали науково-педагогічних читань, присвячених 125-річчю від Дня народження С.Х. Чавдарова, 22 вересня 2017 р.; за заг. ред. А.А. Марушкевич. - Ніжин : ПП Лисенко М.М., 2018. - С. 61-85.

3. Кошечко Н.В. Тренінг "Молодь вибирає конструктивний конфлікт" / Н.В. Кошечко // Наук.-практич. та освітньо-метод. журн. "Практична психологія та соціальна робота", 2005. - N 8-№11.

4. Петрович В.С. Я хочу бути тренером: настільна книга тренерапочатківця / упоряд. В.С. Петрович, О.Ю. Закусило. - Луцьк, 2004. - 70 с.

5. Цюман Т.П. Формування культури життєвого самовизначення старшокласників засобами освітнього тренінгу : автореф. дис. ... канд. пед. наук. 13.00.05 - соціальна педагогіка / Т.П. Цюман. - Інститут проблем виховання АПН України. - Київ, 2008. - 20 с.

6. Шевчук О.М. Організація і методика соціально-педагогічного тренінгу : навч. посіб. / уклад. О.М. Шевчук. - Умань : ПП Жовтий, 2011. - 133 с.

7. Історія виникнення тренінгів. [Електронний ресурс]. - Режим доступу: https://www.rbc.ua/ukr/digests/istoriya-vozniknoveniya-treningov18072013122100

Надійшла до редколегї̈ 12.03.19

Н. Кошечко, канд. пед. наук, доц.

Київський національний університет імені Тараса Шевченка, Київ, Україна

\section{ПРАКТИЧНА ПІДГОТОВКА МАЙБУТНІХ ВИКЛАДАЧІВ ЗАСОБОМ ОСВІТНЬОГО ТРЕНІНГУ 3 ПЕДАГОГІЧНОї КОНФЛІКТОЛОГІї}

Здійснено аналіз актуальних ідей з проблеми практичної підготовки майбутніх викладачів закладів вищої освіти. Зауважено на сучасних технологіях навчання студентів відповідно до їхніх потреб і запитів. Виняткову увагу приділено освітньому тренінгу з педагогічної конфліктології як динамічної форми навчання, під час якого активно засвоюються знання, відбувається набуття умінь $і$ навичок, що відповідає умовам сучасного життя. Освітній треніне спрямований на формування освітньої та життєвої компетентності особистості шляхом збагачення як знаннями, так і життєво-практичним та емоційно-особистісним досвідом. Детально розглянуто зміст, історичний аспект, принципи, етапи, специфіка, вправи та методи освітнього тренінгу у вищій школі, який стає сучасним дієвим інструментом діяльності викладача у вищій школі, а його опанування значно підвищує якість засвоєння не тільки дисципліни "Педагогічна конфліктологія" та інших навчальних курсів, але й загалом професійну й особистісну компетентність і продуктивність студентів за рахунок заощадження часу, ресурсів, творчих перспектив. Педагогічна конфліктологія - теоретико-прикладна царина, що базується на дослідженні сутності, чинників виникнення, специфіки та динаміки педагогічних конфліктів. Педагогічний конфлікт потребує специфічної комплексної методики його профілактики та подолання. Вона полягає в поєднанні методів, технологій і технік індивідуального психологічного консультування (для ефективнішого вирішення внутрішньособистісних конфліктів) із тренінговими технологіями (для оптимального розв'язання міжособистісних конфліктів). Завдяки такому підходу дійсно можна досягнути визначених позитивних зрушень і перетворень у свідомості та поведінці студентів, забезпечити їхню ефективну практичну підготовку як майбутніх викладачів закладів освіти.

Ключові слова: вища школа, освітній треніне, педагогічна конфліктологія, практична підготовка майбутніх викладачів. 